\title{
Determinants of Audit Firm Selection Decision: A Qualitative Study of Firms Listed on Pakistani Stock Exchange (PSX)
}

\author{
MUHAMMAD NAVEED \\ Department of Management Studies, Bahria University, Islamabad. \\ Email: qm.naveed@outlook.com \\ Dr. ALIA QADIR \\ Department of Management Sciences, Riphah International University, Faisalabad Campus. \\ Email: alia.sheeraz@gmail.com \\ MUHAMMAD UMER \\ Department of Management Sciences, COMSATS,Islamabad. \\ Email: mohd.umer@gmail.com
}

\begin{abstract}
The objective of this study is to offer detailed and updated overview of the factors perceived by the audit committee members to select external auditors. Moreover, the study aims to explore that what are the main determinants perceived by the clients from their external auditors. Qualitative research design is used, and open-ended interviews has been conducted to explore the phenomena under investigation. The contextual setting of the study is provided by financial firms listed on Pakistan stock exchange (PSX-100). The study finds that management continues to provide input into the selection decision of external auditors because the audit committees view management as an important information source. Audit committee seeks input from management to assess the external audit accessibility, reputation, firm's industry knowledge and technical expertise. The result of the study suggests that more regulations are required to liable the audit committees for selecting external audit firm. The management input raises the audit risk and mitigate the audit independence. The findings remain robust for audit firms and companies looking for an independent and transparent relationship. Also, the study has implications to build transparent financial disclosure practices.
\end{abstract}

Keywords: Audit Quality, Pakistan Stock Exchange, Clients Perceived Value.

\section{Introduction}

Auditor provide essential services to assure the financial information reliability and integrity. The outcome of audit services remains critical for stakeholder and organization to ensure the financial transparency. Transparent financial reporting remain obligatory and listed firm are being required to publish their audited financial statement, so that stakeholder can make sound investment decision. Therefore, auditor selection decision remains challenging for firms to comply the regulatory requirements and shareholder interest (Kacanski, Lusher \& Wang, 2020). The board of director and particularly the audit committee remain actively involved in the process of auditor section. The board remain obligatory to safeguard the interest of shareholder and ensure the transparent financial disclosure practices (Naveed, Ali, Iqbal \& Sohail, 2020). The stakeholder mainly relies on audited information to make their asset allocation decision (Habib, Bhuiyan \& Sun, 2019; Naveed et al, 2020). 
The audit committee derived from board of director consist both independent and dependent director to oversee the internal control process and assist the external auditing process. According to CCG, (2017) board shall provide necessary resources and authority to audit committee to perform its role and responsibilities effectively. Regarding the selection of an audit firm audit committee also consider the rating under the quality control review program by the Institute of Chartered Accountants of Pakistan. Public listed companies are required to do not select the audit firm which is not compliant with the International Federation of Accountants guidelines on Code of Ethics (CCG, 2017).

All the regulatory provisions are mandatory which guide the selection of audit firm; however, there are some other considerations which are considered by the management and audit committee while hiring an audit firm. Furthermore, perceived value of the audit services by the clients also serve as the criteria for external auditor selection. Various studies expounded in previous literature examined auditor selection and value of audit services (e.g., Kusters, 2016; Yang, Kang, Lin \& Ronen, 2016; Dhaliwal, Lamoreaux, Lennox \& Mauler, 2015; Almer, Philbrick, \& Rupley, 2014; Abbott \& Parker. 2000; Addams \& Allred, 2002; Addams \& Davis. 1994). However, studies in the context of Pakistan are rare and there are insufficient evidences to comprehend the phenomena of auditor selection and audit perceived services by the client.

Also due to recent financial crunch, audit firms are facing hostile competition and losing their clients. Audit firms are particularly concerned about client perceptions that how they select audit firms and how they perceive the value of audit services (Reason, 2010). Firms are looking for insight which can provide reasons behind the selection of an audit firm and how much this selection is attributable to audit fee and relative to other factors. All these dynamics set forth the rationale for this study to explore; what drive the audit firm selection, and what are the client perceptions about the value of audit services they receive (Goddard \& Schmidt, 2020).

Audit base literature mostly contain studies that evaluate the reasons that how clients select audit firms based on survey or archival data (Stefaniak et al, 2009). On the basis of substantive literature review it has been analyzed that no study to date in the context of Pakistan has been conducted in-depth interviews to effectively understand this phenomenon. In-depth interviews are pragmatic to understand the client's perspectives and offer new insights to understand a phenomena more effectively. Therefore, recently there is an increased attention by audit practitioners and researchers conducting and calling for qualitative research related to client perspectives and audit practice to understand behavioral reasons for auditor selection and other services (Bedard et al, 2012; Beattie \& Fearnley, 1998).

Audit researchers also seek toward marketing perspective of clients buying behavior. The clients buying behavior provide the basis for audit firm selection and presumption about audit service value. Client's perceived value about the audit services might be useful when evaluating audit firm selection (Gronroos, 2001). Therefore, the main concern of the propose study is to determine the factor which drive auditor selection and customer perceived value from audit services. This study offers detailed and outline the factors perceived by the audit committee members to select external auditors. Moreover, the study aims to explore that what value clients perceive to receive from their external auditors.

The competitive market environment with dynamic corporate regulation increased the concerns of audit firms, that business entities perceive audit service as a commodity and consider various subjective factors while selecting external auditor. However, the literature based on auditing lacks qualitative insight from business clients on the factors which drive external auditor selection and what are the perceived values of the audit services. Moreover, the regulatory setting of Pakistan as a developing economy pose serious concern about the value of audit services and perceived factors which drive auditor selection. To comprehensively understand the client's perspective, the study aims to conduct detailed unstructured interviews with 10 financial managers who remain involved in process of hiring external auditors. The 
findings of the study will offer new insight to audit firms to build better client relationship and retain their customer. Also, the study will build the body of knowledge in the context of auditing base literature.

\section{Literature Review}

The literature review is organized in two parts. The first part deals with the background literature on auditor selection and the next part deals with the clients perceived value of the audit service. Most of the research expounded in previous literature mainly focuses on how the characteristics of an auditor impact the prospect of selection. The studies evaluate predictor variables, including the audit fee and auditor's industry knowledge. The studies also consider the size of the audit committee and technical expertise of the auditor as a major determinant of auditor selection (Kaplan, O'Donnell \& Arel, 2008; Pflugrath, Martinov-Bennie \& Chen, 2007; Abbott \& Parker, 2000; Chen \& Zhou, 2007; Beasley, Carcello, Hermanson \& Neal, 2009).

However, pre- Sarbanes Oxley Act research considers the auditor selection as the function of management decision. Similarly, in the case of Pakistan pre-CCG the auditor selection was the main responsibility of the management rather than audit committee. However, post-CCG practices contend that external auditor selection is the core responsibility of an audit committee with the discretion of board of director. Moreover, the studies in the context of Pakistan are rare therefore; relevant studies have been reviewed to effectively understand the phenomena.

One of the comprehensive study conducted by Beattie \& Fearnley (1995), examined the auditor choice and auditor quality and revealed two primary but interlinked factors. The first factor is agency demand and second is information demand. The agency demand trigger due to the separation of ownership and control which may be mitigated by reliable financial information (Jensen \& Meckling,1976). The business entities value audit services as a monitoring device because it increase the credibility of the financial statements. Therefore, most of the previous studies correlate the agency demand for auditor quality service to variables such as leverage, firm size and managerial ownership (Francis \& Wilson, 1988).

The information demand is closely related with agency demand. The selection of a reliable and independent auditor signals the quality of management decision making and reduce to agency conflicts (Jensen \& Meckling, 1976). The reliable information dully assured by independent auditor is delicate especially when organizations need equity financing. Therefore, the auditor selection remains crucial element for management to acquire the benefits of low equity and debt financing.

As discussed above, studies expounded in previous literature typically modeled auditor selection as the management related variable. However, the new regulatory changes increased the pace of studies examining the role of audit committees in external auditor selection process.

\section{Audit Committees and Auditor Selection}

According to Fama (1980) and Fama \& Jensen (1983), board of director an important monitoring device plays a vital role in overseeing the management decision making behavior. Board of director consist both independent and dependent director, independent director are usually high-reputation members of the business community assigned with the responsibility of protecting shareholder interest. These independent directors also become the member of audit committees delegated with financial oversight (Chan \& $\mathrm{Li}$, 2008). According to recent regulatory changes (CCG, Pakistan) audit committees are responsible for external audit selection. Therefore, the role of independent director is increased due to their independent position to select an independent external auditor. Audit committees which comprise independent director have a high propensity to select the external auditor which is more independent and offer high value audit services. 
However, research reveals that even post-SOX, management exercise control over the appointment of external auditor (Cohen et al, 2010). If the management instead of audit committee appoint the external auditor, auditor will be more likely to fulfill the preferences of management (Saul, 1996). Hence the role of institutional arrangements that strengthen the role of audit committee in external auditor selection will likely to strengthen the auditor independence.

The substantive review of the audit literature reveals that mainly there are two perspectives through which the issue of auditor selection has been examined. Firstly pre-SOX research examines the management role in selection of external auditor and post-SOX studies consider the function of audit committee to participate the in the process of audit firm selection. The post-SOX studies modeled variable of audit committee characteristics, audit committee composition, audit committee diligence and technical expertise of the audit committee member. The next important factor which drives the selection of an auditor is the audit fee and audit firm reputation, which is widely examined by both pre and post SOX studies (Brown, 2016). The quality of audit committee composition and delegation of auditor appointment responsibility leads to relax the agency conflicts and effectively justify the agency cost.

On the basis of literature review, this study focuses on the audit committee's role in external auditor selection for two reasons. First, the selection and retention of external auditor with the discretion of corporate board is a basic responsibility of the audit committee (CCG, 2010; Dhaliwal, Lamoreaux, Lennox $\&$ Mauler, 2015). The audit committees are responsible for evaluating the independence of external auditor to effectively protect the interest of shareholder. Second, due to the legal position of the audit committee, audit committee members have strong incentives to protect their legal liability and reputational capital. An effective audit committee assumes the legal responsibility for the engagement of external auditor and monitors the firms accounting functions (Gold, Klynsmit, Wallage \& Wright, 2015).

The research conducted by Almer, Philbrick \& Rupley (2014), provides evidence about the factors which impact auditor selection. The study finds that management play active role in the selection process of external auditors because the audit committees view management as an important information source. Audit committee seeks input from management to assess the external audit accessibility, reputation, firm's industry knowledge and technical expertise. The result of the study suggests that more regulations are required to liable the audit committees for selecting external audit firm. The management input raises the audit risk and mitigate the audit independence.

Corporate governance also recognizes the importance of audit committee due to its regulatory and public interest. According to corporate governance perspective active and independent audit committee members demand a high level of audit quality. Audit committee remains concerned about the independence of external auditor because of reputational losses that may result from SEC sanction and lawsuits. Audit committees therefore, select external auditors who particularly specialize in clients industry to provide a higher quality audit and other value added service to reflect the credibility of accounting information (Khoo, 2016).

As discussed earlier, outside or independent directors on audit committee demand a high level of auditor quality. Hence, the independent directors exercise a substantial affect over the selection of an external auditor. Previous studies also hypothesize that directors with finance and accounting background have a significant impact on the independence of external auditor. This seems rational due to the fact that directors who have a relevant experience and knowledge of audit better understand the process of audit and therefore, in better position to select the auditor which possess superior knowledge and relevant experience. However, previous studies theorize a mixed view about the presence of independent director on audit committee and auditor selection. Cottell \& Rankin (1998), claimed that the presence of independent directors on audit committee has no such effect on the selection and change of an external auditor. Eischenseher \& Shields (1985), find a positive association between audit committee and selection of an 
external audit firm. However, it is argued that only the presence of audit committee is not sufficient, the activity and composition of the audit committee is required to independent auditor choice.

Audit committees which are independent from management may have incentives to support management's preferences that outweigh liability related incentives. Audit committees which are inactive and less likely to influence board or management decisions, have less participation in the process of auditor selection and therefore, heavily impact the independence and quality of external audit (Christensen,Omer, Shelley \& Wong, 2015). This argument also extends the notion that audit committee composition and characteristics are not only sufficient to affect the external auditor selection, but also the decision making power and independence of the audit committee are required to select an effective external auditor.

On the basis of substantive literature review, it is deduced that most of the previous studies examined the phenomena of auditor selection by using quantitative paradigm instead of qualitative paradigm. However, the phenomena of auditor selection is subjective in nature and survey based studies does not effectively respond the reasons which drive auditor selection. Although it is mandatory by law and regulations that audit committee are liable to select the external auditor however, most of the studies expounded in literature posit that management exhibits a significant influence over the external audit selection.

The reason and justification for management influence is due to the fact that audit committees consider management as the source of information to make appointment decision. As it is discussed earlier that audit committee consist both independent and dependent member, external auditor have a little knowledge about the organization. Hence, external director has to rely on management to make informed decision making (Almer, Philbrick, \& Rupley, 2014; Abbott \& Parker. 2000; Addams \& Allred, 2002; Addams \& Davis. 1994). The study therefore, incorporate question that how management affect the auditor selection decision and how audit committees consider the audit firm services and their respective value.

The next important question which is selected to examine is client perceptions about value of audit services. According to marketing perspective services are also commodities; therefore, clients value those products which are valuable to them and satisfied their need. The next section of the literature reviewed the studies which particularly examined the value of audit services as perceived by the firms.

\section{Clients Perceive Value of the Audit Service}

Most of the previous studies expounded in literature have not examined the value of the audit service as perceived by the clients. The value and importance of audit service which clients perceive from their auditor is one of the elements considered in deciding whether to select or switch an external auditor. The marketing perspective argued that services which contain utility and value remain robust to mitigate customer intention toward switching and aggravate customer retention. Moreover, marketing base literature support to gain new insight about selection behavior of the client, as previous studies focus on economic reason as the only core description of client's behavior (Beattie et al. 2000).

Core value is concerned with the standard solution a product or service is designed to produce, while the added value is subject to offer additional services which delight the customer and increase customer loyalty. In the context of auditing core value entails the independent examination of the books of account to reflect their credibility and integrity and provide an opinion. On the other hand added value entails providing additional service such as tax advice, formulation of annual reports and compliance with the dynamic rules and regulation. These additional services increase client's retention and reduce clients switching (Addams \& Allred, 2002).

However, audit services which contain added value may deviate from the core value and reduce the auditor independence. Therefore, studies expounded in audit base literature also advocate that offering tax advice and other supporting service by audit firms significantly affect auditor independence (Berg \& Moré, 2016). 
Therefore, current study particularly considers this aspect and aims to determine that either value audit services leads to reduce auditor independence or not.

Client's perceived value about audit services is one of the major aspects which are considered while making external auditor selection. The service marketing base literature guide the research question to investigate that what type of value clients considered more when making selection decision of external auditor. The examination of this question will leads to better guide the audit firm to exhibit those services clues which are most valued by clients. The exploration of these clues will assist the audit firms to improve relationship with customer and reduced customer switching.

\section{Research Methods}

To explore what value clients, perceive, from external audit and how they select external auditor, openended question has been developed and used for interviews with financial managers. The interview questions are based on research objectives and guided by conceptual framework respectively. Fundamental qualitative description is selected as the research design for sampling, data collection technique and analysis procedure. The qualitative research design is employed to gain a comprehensive insight about the issue under investigation. This type of research design is best suited when it is aimed to respond the questions about specific events or phenomena (Creswell, 2013). A purposeful sample of ten financial managers (Director) currently or formerly involved in making appointment decision of external audit are selected by using convenient sampling technique. These director or financial manager was from public listed companies who remain liable to conduct external audit for each financial year. Contextual setting of the study is provided by public companies which acquire the services of external auditor to fulfill the regulatory requirements of Security Exchange Commission of Pakistan. The current study employed unstructured open-ended in-depth interviews to gain comprehensive insight about the factors which drive auditor selection and client's perceived value of audit services. An interview implies some form of verbal discourse. The key informant interviews provide the rich information about the issue under investigation (Maxwell, 2012). Nvivo-11 research tool will be used to formulate word frequency report, open coding Finally based on significant themes qualitative model of the study will be developed.

\section{Theoretical Framework \& Discussion}

Based on substantive literature review and open-ended interviews conceptual model of auditor selection and perceived audit value is formulated. Theories expounded in previous literature advocate various determinants which drive the selection of an audit firm; however, collectively there are two major constructs which are exceptional. The conceptual model of the current study based on marketing perspective of customer perceived value reflects that core value and added value are major construct which determine the auditor selection. However, the relationship between auditor and clients also impede the auditor selection criteria. Rest of the paper discusses the major determinants based on literature and indepth interview which glean the customer perception to select an audit firm.

\section{Core Values from Audit Profession}

The basic motive of an audit is to validate the complex accounting issues and identification of fraud and error. The identification of fraud and mistake validate the accounting data to reflect the true picture of organizational financial health. Furthermore, the core audit services increase the transparency and disclosure of accounting data to enable the shareholder to make sound decision making. The auditor examination also provides reasonable assurance regarding the compliance with national and international financial reporting standards (Berg \& Moré, 2016). Therefore, the quality of core values remains integral for corporation hiring audit firms. The conceptual model of the study reflects following two major dimensions of core values in the context of audit profession. Most of the studies reviewed also advocate that validation of accounting data and independence of an auditor remains central to selection. 


\section{Auditor Validation}

Most of the valuable services firms seek form their audit firms is to validate the accounting data. The main responsibility of the auditor is to examine the compliance of different accounting and financial reporting standards. Beside routine vouching and verification an auditor also observe the compliance of various international accounting (International Accounting Standards) and financial reporting standards (IFRS). The audit report provide reasonable assurance to the user of accounting information that firm is reflecting the true picture of business (Gronroos, 2001). Therefore, auditor validation services are not only significant to clients but also for user of accounting information (Naveed et al, 2020). Therefore, an audit committee perceived the validation service as the major criteria for auditor selection. Organizations seek auditor guidelines to prepare their financial statements accounting to the governing laws. Accordingly audit firms which are more proficient in providing validation services outperform in gaining more clients.

\section{Independence}

The auditor independence is critical to the whole audit process and purpose. Being independent means an auditor should be free from any bias and pressure. Bias means auditor personal cognitive judgments should be ignored and professional skepticism should be used for the opinion about organization being audited. Auditor should also remain free form any internal and external pressure to from his opinion. Audit committees which make the audit firm selection consider both these considerations while making hiring decision of an auditor. Audit theory also recognizes both these construct as the main qualities and competencies of an auditor. Beside, these core values relevant to the professional skepticism of audit there are value added services which also drive the audit committee auditor selection process (Berg \& Moré, 2016).

\section{Value Added Services}

The client wants to go beyond the core audit services and seek more business advice for the auditor. The clients see audit firm as a source of large network of partners and other clients for different industries and different geographical areas. Furthermore, like advice regarding corporate tax and implication of various accounting and financial reporting standards. Therefore, audit firms should not only focus to improve their core audit function but also additional services to retain the customer. On the basis of conceptual model, the following two main services are perceived as value added services.

\section{Auditor Industry Knowledge}

Technical expertise and relevant industry experience remain valued by clients. Both these requisite skills are needed to identify and state accounting issues on timely basis and the quality of written proposal. The industry knowledge serves as the added benefit and advantage to the clients and audit firm equally. The industry knowledge is preferred by clients while selecting and auditor. The auditor having industry knowledge will be proficient in understanding the asset and liabilities valuation methods. Also, auditor advice becomes more influential and beneficial when auditor possesses the respective industry experience and knowledge.

\section{Additional Advice}

Clients also need audit firm support to provide additional insight about application and interpretation of accounting standards. Also, firm seeks advice to use creative accounting method with the consultation of audit firm to reflect a good picture of their business through financial reporting. Moreover, clients also need tax advice and appropriateness of their asset valuation methods. The firm also expects that auditor examine and verify the robustness of internal control. These additional services form the auditor are central to get hired and retain by the client. Audit firm which provide the accounting policies and supervision of internal 
control perceive assistance of an auditor to provide guideline for formulating and implementing such policies. Therefore, the audit firm may consider these services as the central concern while making hiring decision of an auditor (Khoo, 2016). Core value- and value-added services remain integral to drive the auditor selection however, the relationship between auditor and client also impact the hiring and switching behavior of clients.

\section{The Auditor- Client Relationship}

The auditor- client relationship is different from other typical buyer and select relationship due to the fact that clients are paying for services which they are not the intended user. The audit report largely serves the interest of outsider such as investor, banker, and investor. The value of the audit report for the external users is based on an independent auditor. Therefore, auditor needs to remain distant from the client raises the question of what value does the audit provide tot the clients. Accordingly, audit theory it is also advocated that clients do not perceive audit as important because it provide more value to outsider user. Therefore activates besides verifying financial statements are considered as by product of the audit (Abbott \&Parker, 2000). Clients do not value core audit services but they perceive value in additional services such as advice form auditors. Therefore alternate theoretical perspective should be adopted to understand the factors which drive client's satisfaction. According to marketing theory of customer perceived value, clients compare the cost and value of auditor while making hiring decision. Therefore, audit committee and management consider value added services as one of the major factor while making auditor hiring decision.

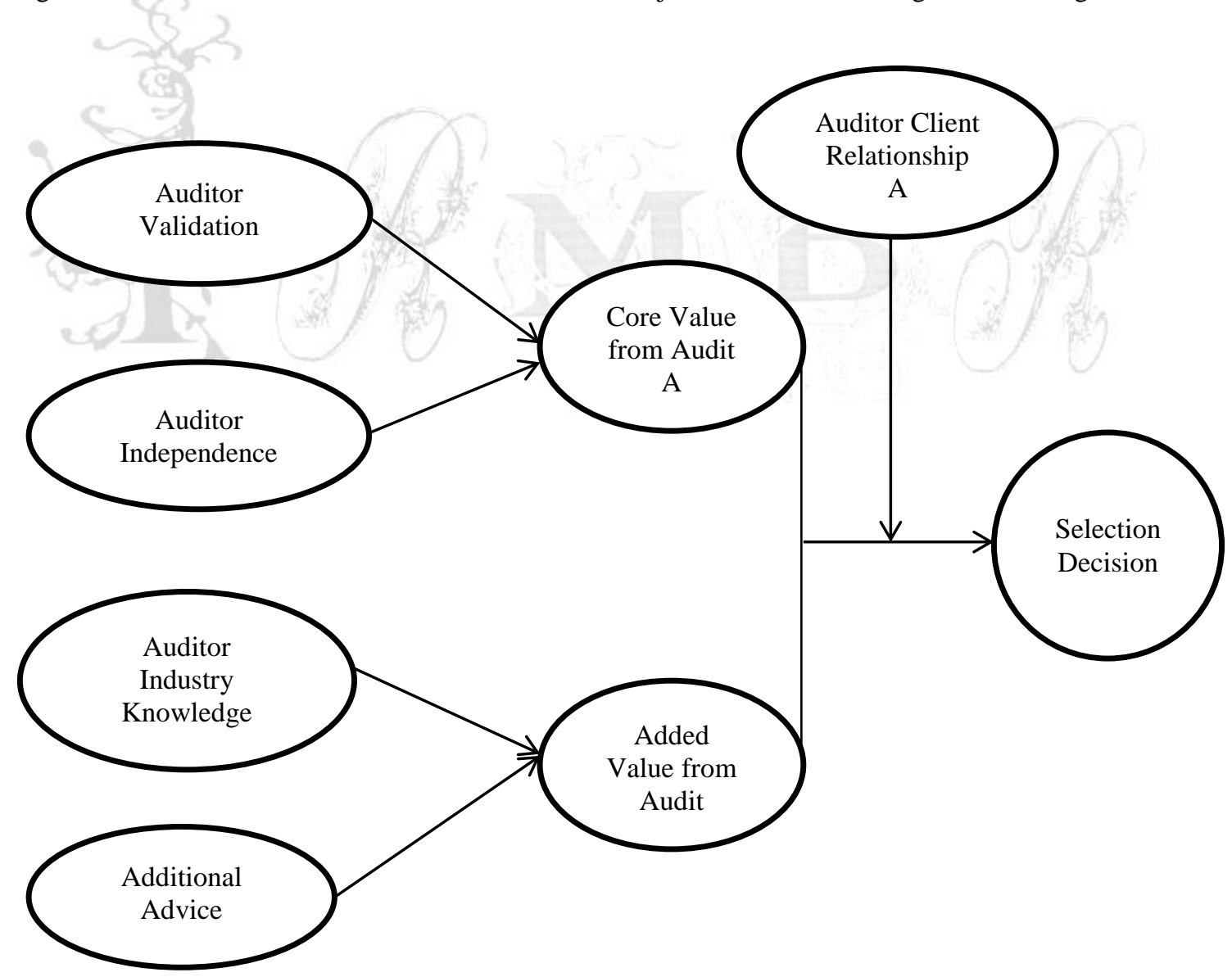

Figure 1: Conceptual Model 


\section{Conclusion}

The basic objective of this study was to determine the factor which drives auditor selection and customer perceived value from audit services. On the basis of substantive literature review and in-depth interviews was develop to understand the factors which derive auditor selection. Auditor selection remains one of the major functions of an audit committee. Audit committee besides guiding the accounting policies of an organization also remains liable to selects the auditor to perform external audit. The external audit validates the accounting data and provides assertion to shareholders that firm financial data reflect the true picture of business. Therefore, the relationship between auditor and firm remain diverge than usual buyer seller relationship. The auditor is being selected by firms however; largely they serve the interest of external user of financial statements.

The firm on the other hand paying audit fees to auditor have no keen interest in auditing process. The audit theory also confirms that firm remains less concern about the auditor services because they largely serve the interest of external users. Therefore, the current study evaluates this unusual relationship between auditor and firm by using service marketing theory. The marketing theory of customer perceived value posit that customer compares price and value of a product as compared to other products Carcello, Hermanson \& Neal, 2009). Furthermore, according to customer perceived value (CPV), customer perceived core value- and value-added services when making a purchase decision. According to marketing perspective firms hiring auditor also seek these two types of values while making hiring decision of an auditor. The current study deduced the conceptual model of the study based on marketing theory of CPV. According to the model of the study majorly there are two types of values audit committees perceived while making hiring decision of an auditor. Audit committee considers validation and independence of an auditor as the core value from an audit process.

The core value is necessary for meeting regulatory requirements and obtaining an unqualified audit report. An unqualified audit report assures to the external user that financial statements of an organization contain no serious departure from international accounting and reporting standards. However, from firm and auditing theory perspective the core value of an audit is a byproduct service. Therefore, firms seek value added services which are beyond the scope of usual audit services. The value added audit services according to CPV largely drive the selection of an audit firm. The value added service according to the conceptual model contains industry knowledge and additional advice form auditors. Therefore, on the basis of conceptual model of the study and previous literature it is argued that audit committee commonly perceives more value to value added services. The firm pays more attention to value added services while making hiring decision of an auditor. Therefore, audit firm should pay more attention to value added services while conducting the external audit to retain and attract the client. The extra services beside core value services makes customer more loyal and retentive. The current study draws conclusion on the basis of substantive literature review however, future studies may use qualitative approach to disclose more factors which drive the auditor selection. The future studies may use interview methods to explore the factors which are most perceived by audit committee while selecting an audit firm.

\section{References}

Abbott, L., and S. Parker. (2000). Auditor selection and audit committee characteristics. Auditing: A Journal of Practice \& Theory 19 (2): 47-66

Abbott, L., and S. Parker. (2000). Auditor selection and audit committee characteristics. Auditing: A Journal of Practice \& Theory 19 (2): 47-66.

Addams, H., and A. Allred. (2002). Why the fastest-growing companies hire and fire their auditors. The CPA Journal(May): 62-63

Addams, H., and B. Davis. (1994). Privately held companies report reasons for selecting and switching auditors. The CPA Journal (August): 38-41. 
Almer, E. D., Philbrick, D. R., \& Rupley, K. H. (2014). What Drives Auditor Selection?. Current Issues in Auditing, 8(1), A26-A42.

Be' dard, J., Y. Gendron, D. R. Hermanson, and C. Humphrey. (2012). Doing Field Research in Auditing. Research Panel Presentation at the 2012 AAA Auditing Section Midyear Conference and Doctoral Consortium, Savannah, Georgia.

Beasley, M. S., Carcello, J. V., Hermanson, D. R., \& Neal, T. L. (2009). The audit committee oversight process. Contemporary Accounting Research, 26(1), 65-122.

Beattie, V., and S. Fearnley. (1998). Audit market competition: Auditor changes and the impact of tendering. British Accounting Review 30 (3): 261-289

Beattie, V., S. Fearnley, and R. Brandt. (2000). Behind the audit report: A descriptive study of discussions and negotiations between auditors and directors. International Journal of Auditing 4 (2): 177-202.

Berg, S., \& Moré, C. (2016). The Effect of Non-Audit Services on Auditor Independence: A study on 11 food retail-and wholesale companies in the United Kingdom.

Brown, V. L. (2016). The Effects of Manager-Auditor Affiliation and PCAOB Inspection Reports on Audit Committee Members' Auditor Selection. Current Issues in Auditing.

Chan, K. C., \& Li, J. (2008). Audit committee and firm value: evidence on outside top executives as expertindependent directors. Corporate Governance: An International Review, 16(1), 16-31.

Chen, K. Y., \& Zhou, J. (2007). Audit committee, board characteristics, and auditor switch decisions by Andersen's clients. Contemporary Accounting Research, 24(4), 1085-1117.

Christensen, B. E., Omer, T. C., Shelley, M. K., \& Wong, P. A. (2015). Audit Committee Influence on Audit Firm Selection, Retention, Efficiency, and Fees. Retention, Efficiency, and Fees (August 4, 2015).

Code Of Corporate Governance,(2012). Security Exchange Commission of Pakistan, SECP, 2016. Print.

Cohen, J., G. Krishnamoorthy, and A. Wright. (2010). Corporate governance in the post-Sarbanes-Oxley era: Auditors' experiences. Contemporary Accounting Research 27 (3): 751-786

Cottell, P. G., and L. J. Rankin. (1988). Do audit committees bias auditor selection? Akron Business and Economic Review 19 (4): 87-103

Creswell, J. W. (2013). Qualitative inquiry and research design: Choosing among five approaches. Sage.

Dhaliwal, D. S., Lamoreaux, P. T., Lennox, C. S., \& Mauler, L. M. (2015). Management Influence on Auditor Selection and Subsequent Impairments of Auditor Independence during the Post-SOX Period. Contemporary Accounting Research, 32(2), 575-607.

Dhaliwal, D. S., Lamoreaux, P. T., Lennox, C. S., \& Mauler, L. M. (2015). Management Influence on Auditor Selection and Subsequent Impairments of Auditor Independence during the Post-SOX Period. Contemporary Accounting Research, 32(2), 575-607.

Eichenseher, J. W., and D. Shields. (1985). Corporate director liability and monitoring preferences. Journal of Accounting and Public Policy 4 (1): 13-31.

Francis, J. R., and E. R. Wilson. (1988). Auditor changes: A joint test of theories relating to agency costs and auditor differentiation. The Accounting Review 63 (4): 663-683

Goddard, F., \& Schmidt, M. (2020). Attributes Influencing Clients' Auditor Choices: The Expectation Gaps between Auditors and Board Members. Current Issues in Auditing, 0000-0000.

Gold, A., Klynsmit, P., Wallage, P., \& Wright, A. (2015). The Impact of Auditor Selection Regime and Audit Committee Appointment Power on Investment Decisions. Available at SSRN 2484415.

Gronroos, (2001) Service Management and Marketing. New York, NY: Wiley.

Habib, A., Wu, J., Bhuiyan, M. B. U., \& Sun, X. (2019). Determinants of auditor choice: Review of the empirical literature. International Journal of Auditing, 23(2), 308-335.

Jensen, M., and W. Meckling. (1976). Theory of the firm: Managerial behavior, agency costs and ownership structure. Journal of Financial Economics 3: 305-360.

Kacanski, S., Lusher, D., \& Wang, P. (2020). Auditor Selection Process: An Interplay of Demand Mechanisms-A Multilevel Network Approach. European Accounting Review, 1-28.

Kaplan, S. E., O'Donnell, E. F., \& Arel, B. M. (2008). The influence of auditor experience on the persuasiveness of information provided by management. Auditing: A Journal of Practice \& Theory, 27(1), 67-83. 
Khoo, M. S. (2016). Auditor Selection and Retention: The Australian Mining IPO Market.

Kusters, R. (2016). The Impact of Board interlocks on Auditor Choice in the Netherlands.

Maxwell, J. A. (2012). Qualitative research design: An interactive approach: An interactive approach. Sage. Naveed, M., Ali, S., Iqbal, K., \& Sohail, M. K. (2020). Role of financial and non-financial information in determining individual investor investment decision: a signaling perspective. South Asian Journal of Business Studies.

Naveed, M., Sohail, M. K., ul Abdin, S. Z., Awais, M., \& Batool, N. (2020). Role of ESG Disclosure in Determining Asset Allocation Decision: An Individual Investor Perspective. Paradigms, 14(1), 157166.

Pflugrath, G., Martinov-Bennie, N., \& Chen, L. (2007). The impact of codes of ethics and experience on auditor judgments. Managerial Auditing Journal, 22(6), 566-589.

Reason, T. 2010. Auditing your auditor. CFO Magazine (April 1). Available at: http://www.cfo.com/article.cfm/14485723

Saul, R. S. (1996).What ails the accounting profession? Accounting Horizons 10 (2): 131-137.

Yang, Y. J., Kang, J., Lin, R. C., \& Ronen, J. (2016). Auditor selection within a business group: evidence from Taiwan. Review of Quantitative Finance and Accounting, 46(2), 195-215.

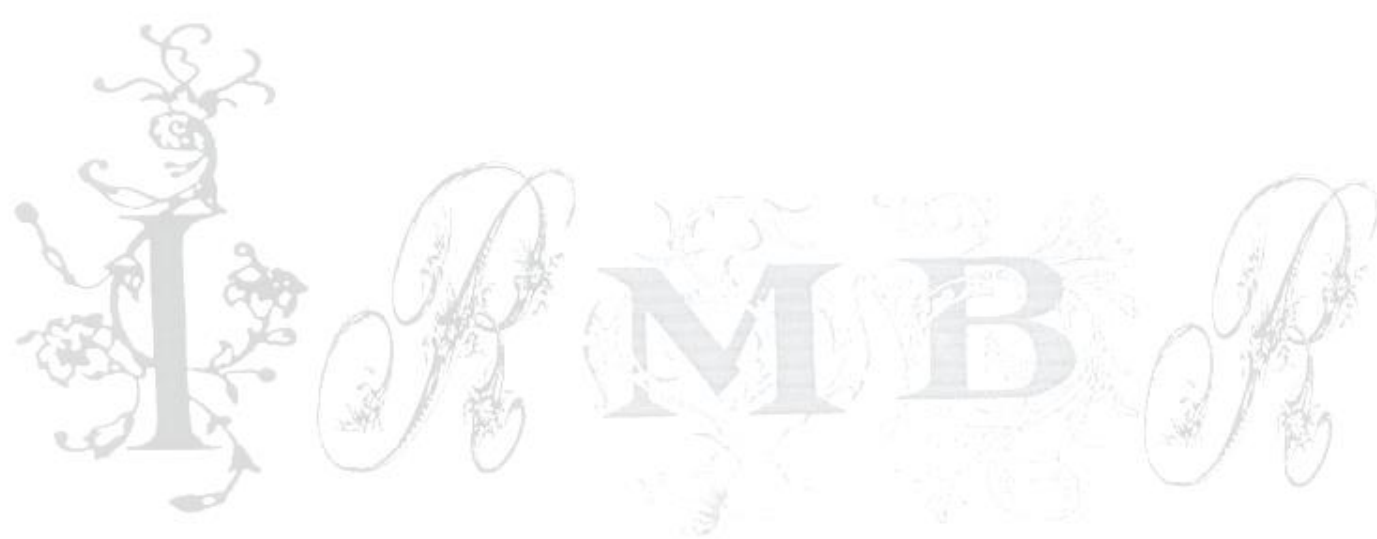

